Short Note

\title{
Bioactive Peptides in Milk: From Encrypted Sequences to Nutraceutical Aspects
}

\section{Massimo Lucarini}

Consiglio per la Ricerca in Agricoltura e l'Analisi dell'Economia Agraria-Centro di Ricerca Alimenti e Nutrizione (CREA-AN), Via Ardeatina 546, 00178 Roma, Italy; massimo.lucarini@crea.gov.it; Tel.: +39-065-149-4446

Academic Editor: Alessandra Durazzo

Received: 30 May 2017; Accepted: 2 August 2017; Published: 14 August 2017

\begin{abstract}
Milk provides a wide range of biologically active compounds that protect humans against diseases and pathogens. The purpose of this work is to describe the main aspects and research lines concerning bioactive peptides: from their chemistry, bioavailability, and biochemical properties to their applications in the healthcare sector. In this context, the uses of bioactive peptides in nutraceutical and functional foods have been highlighted, also taking into account the perspective of innovative applications in the field of circular bioeconomy.
\end{abstract}

Keywords: bioactive peptides; milk; nutraceuticals; bioavailability; biorefinery

\section{Bioactive Components of Milk: Focus on BPs}

Milk provides a wide range of biologically active compounds that protect humans against diseases and pathogens such as immunoglobulins, antimicrobial proteins and peptides, oligosaccharides, lipids, as well as many other components at low concentrations with significant potential health benefits [1] (Figure 1). Among these compounds, proteins play a key role as nutrients and as promoters of the physiological function and health role as source of Bioactive Peptides (BPs) [2].

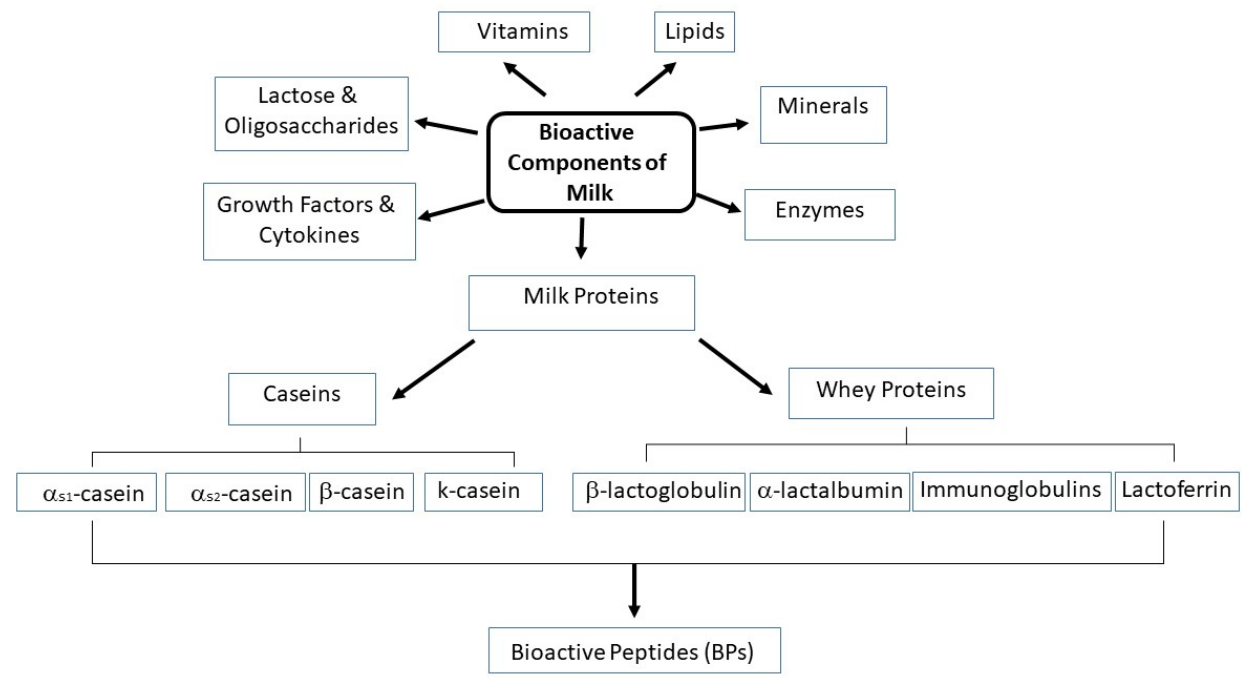

Figure 1. Major bioactive functional compounds derived from milk (adapted fom [1]).

In cow's milk, around $80 \%$ of the protein present is casein $(\mathrm{CN})$ and $20 \%$ is whey protein. $\mathrm{CN}$ consists of $\alpha \mathrm{s} 1-, \alpha \mathrm{s} 2-, \beta$ - and $\mathrm{k}-\mathrm{CN}$ families in the approximate ratio 38:11:38:13 [3]. Whey proteins are typically a mixture of beta-lactoglobulin $(\sim 65 \%)$, alpha-lactalbumin $(\sim 25 \%)$, bovine serum albumin $(\sim 8 \%)$, lactoferrin, and immunoglobulins. The value of proteins as an essential source of amino acids 
has been well documented, but in the 1980s, it was recognized that dietary proteins can exert many other in vivo functions through BPs. The isolation of endogenous opioid peptides called enkephalins, which occurred for the first time in 1975, led to the discovery of the opioid peptide activity derived from partial enzymatic digestion of milk proteins [4]. Since then, the bioactive components derived from food proteins, in particular from milk proteins, have been subjected to numerous studies focused on their structural and biochemical properties.

\section{Biochemical Properties}

BPs peptides are encrypted and inactive in the parent protein sequence but can be released and activated through the enzymatic proteolysis (gastrointestinal digestion, in vitro hydrolysis using proteolytic enzymes) of proteins and during food processing (cooking, fermentation, ripening). Once released, the BPs can act as regulatory compounds such as $\beta$-casomorphins and casein-derived phosphopeptides and are released in vivo during the gastrointestinal transit of milk and dairy products [5]. It is important to underline the strong connection between the structure and the biological activities: the amino acid sequence, the hydrophobicity, the charge of BPs determine a specific activity.

For instance, in the case of $\beta$-casomorphins (BCMs), the presence of a tyrosine residue at the amino terminal end (except $\delta$-casein opioids) and the presence of aromatic amino acids in the third and fourth positions of the peptide represents a structural feature of the opioid activity; in particular, the phenolic hydroxyl group of tyrosine gives rice a negative potential, essential for the opioid activity. On the other hand, the Pro residue maintains the proper orientation of the Tyrosine and Phenylalanine side chains [6,7]. In regard to the importance of the amino acid sequence on the activity of BPs, human BCMs (Tyr-Pro-Phe-Val-Glu-Pro-Ile) were found to be 3 to 30 times less potent than bovine BCMs (Tyr-Pro-Phe-Pro-Gly-Pro-Ile) [7].

The production and properties of BPs have been reviewed in many articles [8-10]. After ingestion, BPs can affect the cardiovascular, nervous, gastrointestinal, and immunological systems. BPs have been defined as specific protein fragments having a positive influence on the physiological and metabolic functions or conditions of the body. Therefore, they may have crucial beneficial effects on human health [11].

Furthermore, it is worth mentioning the recent review of Nielsen et al. [12], where a comprehensive database of milk protein-derived BPs that can be used to search for specific functions-those of peptides or proteins-was developed. A new visual arrangement was proposed: BPs were visually mapped on the basis of parent protein sequences, providing information on sites with the highest abundance of these compounds (http://mbpdb.nws.oregonstate.edu/).

Their main regulatory effects concern the following:

- the transport of minerals (caseinophosphopeptides), such as calcium, and intestinal transport of amino acids, such as leucine, through the beta-casomorphin receptors;

- the transport of intestinal fluid (beta-casomorphine);

- the motility of the gastrointestinal tract (beta-casomorphine);

- the stimulation of the postprandial hormone secretion (insulin, somatostatin) (beta-casomorphine);

- the regulation of insulin secretion based on glucose concentration;

- immunostimulant peptides (alpha and beta casein fragments);

- anti-hypertensive peptides enzyme inhibitors converting angiotensin I (ACE) (casokinine);

- antithrombotic peptides such as ADP-activated platelet aggregation inhibitors, as well as fibrinogen binding ( $\gamma$-chain) to ADP-treated platelets (casoplateline);

- opioid activities;

- antioxidative functions;

- hypocholesterolemic activities;

- antitumor activities. 
Table 1. Examples of bioactive peptides from milk.

\begin{tabular}{|c|c|c|c|c|c|c|}
\hline Precursor Protein & Fragment & Peptide Sequence & Name & Biological Activity & Preparation & References \\
\hline \multicolumn{7}{|l|}{ Casein Protein } \\
\hline \multirow{11}{*}{$\beta$-casein } & $60-70$ & YPFPGPIPNSL & $\beta$-casomorphin-11 & Opioid & $\begin{array}{l}\text { Hydrolysis with digestive } \\
\text { enzymes Trypsin }\end{array}$ & [13] \\
\hline & $60-66$ & YPFPGPI & $\beta$-casomorphin-7 & $\begin{array}{l}\text { Opioid ACE Inhibitory } \\
\text { Immunomodulatory }\end{array}$ & $\begin{array}{l}\text { Mixture of gastro-intestinal } \\
\text { enzymes Trypsin }\end{array}$ & [14] \\
\hline & $60-64$ & YPFPG & $\beta$-casomorphin-5 & Opioid ACE Inhibitory & Hydrolysis with trypsin & [15] \\
\hline & $177-183$ & AVPYPQR & $\beta$-casokinin-7 & ACE Inhibitory & Hydrolysis with trypsin & [15] \\
\hline & 193-202 & YQQPVLGPVR & $\beta$-casokinin-10 & $\begin{array}{c}\text { ACE Inhibitory } \\
\text { Immunomodulatory }\end{array}$ & Hydrolysis with trypsin & [16] \\
\hline & $169-175$ & KVLPVPQ & & ACE inhibition & Hydrolysis with proteinase & [17] \\
\hline & $63-68$ & PGPIPN & Immunopeptide & Immunomodulatory & Trypsin or chymosin & [18] \\
\hline & 191-193 & LLY & Immunopeptide & Immunomodulatory & Trypsin or chymosin & [18] \\
\hline & $114-118$ & YPVEP & ßcasochemotide-1 & Immunomodulatory & Hydrolysis with proteinase & [19] \\
\hline & $210-221$ & EPVLGPVRGPFP & & ACE-inhibition & Fermentation & [20] \\
\hline & $(1-25) 4 \mathrm{P}$ & RELEELNVPGEIVESLSSSEESITR & Caseinophosphopeptide & $\mathrm{Ca}++$ binding & Trypsin or chymosin & [21] \\
\hline \multirow{7}{*}{$\alpha \mathrm{s}_{1}$-casein } & $90-96$ & RYLGYLE & $\alpha$-casein exorphin & Opioid & Hydrolysis with pepsin & [22] \\
\hline & $90-95$ & RYLGYL & $\alpha$-casein exorphin & Opioid & Hydrolysis with pepsin & [22] \\
\hline & $91-96$ & YLGYLE & $\alpha$-casein exorphin & Opioid & Hydrolysis with pepsin & [22] \\
\hline & $23-27$ & FFWAP & $\alpha \mathrm{s}_{1}$-Casokinin-5 & ACE inhibition & Hydrolysis with trypsin & [16] \\
\hline & $28-34$ & FPEWFGK & $\alpha \mathrm{s}_{1}$-Casokinin-7 & ACE inhibition & Hydrolysis with trypsin & [16] \\
\hline & 194-199 & TTMPLW & $\alpha \mathrm{s}_{1}$-Casokinin-6 & $\begin{array}{c}\text { ACE inhibition, } \\
\text { Immunomodulatory }\end{array}$ & Hydrolysis with trypsin & [23] \\
\hline & $169-193$ & LGTQYTDAPSFSDIPNPIGSENSEK & & ACE-inhibition & Trypsin or chymosin & [24] \\
\hline
\end{tabular}


Table 1. Cont

\begin{tabular}{|c|c|c|c|c|c|c|}
\hline Precursor Protein & Fragment & Peptide Sequence & Name & Biological Activity & Preparation & References \\
\hline \multirow{2}{*}{$\alpha \mathrm{s}_{2}$-casein } & $94-103$ & QKALNEINQF & & Antimicrobial ACE inhibition & $\begin{array}{l}\text { Hydrolysis with } \\
\text { chymotrypsin }\end{array}$ & [25] \\
\hline & $163-176$ & TKKTKLTEEEKNRL & & ACE inhibition & $\begin{array}{l}\text { Hydrolysis with } \\
\text { chymotrypsin }\end{array}$ & [25] \\
\hline \multirow{4}{*}{ k-Casein } & $33-38$ & SRYPSY & Casoxin 6 & Anti-Opioid & Hydrolysis with pepsin & {$[26]$} \\
\hline & $25-34$ & YIPIQYVLSR & Casoxin C & Anti-Opioid & Hydrolysis with trypsin & {$[27]$} \\
\hline & $106-116$ & MAIPPKKNQDK & Casoplatelin & $\begin{array}{l}\text { Antithrombotic:inhibition of } \\
\text { platelet aggragation }\end{array}$ & Hydrolysis with trypsin & {$[28]$} \\
\hline & & YPSY & Casoxin 4 & Opioid agonist & Synthetic & [29] \\
\hline \multicolumn{7}{|l|}{ Whey Proteins } \\
\hline$\alpha$-lactalbumin & $50-53$ & YGLF & $\alpha$-lactorphin & Opioid agonist ACE inhibition & $\begin{array}{l}\text { Hydrolysis with gastric and } \\
\text { pancreatic enzymes }\end{array}$ & [30] \\
\hline$\beta$-lactoglobulin & $102-105$ & TLLF & $\beta$-lactorphin & Non-opioid ACE-inhibition & Tryptic digest & [31] \\
\hline \multirow[b]{2}{*}{$\beta$-lactoglobulin } & $142-148$ & ALPMHIR & & ACE-inhibition & Proteolytic digestion & {$[32,33]$} \\
\hline & $146-149$ & HIRL & $\beta$-lactotensin & $\begin{array}{c}\text { Ileum contraction, } \\
\text { hypocholesterolemic activity }\end{array}$ & Synthetic & {$[31,34]$} \\
\hline \multirow{2}{*}{$\begin{array}{l}\text { Bovine Serum } \\
\text { Albumin }\end{array}$} & $208-216$ & ALKAWSVAR & Albutensin A & $\begin{array}{l}\text { Ileum contraction, } \\
\text { ACE inhibition }\end{array}$ & Hydrolysis with proteinase & [32] \\
\hline & $399-404$ & YGFQDA & Serorphin & Opioid & Hydrolysis with pepsin & [35] \\
\hline Lactoferrin & $17-41 / 42$ & FKCRRWQWRMKKLGAPSICURRAF/A & Lactoferricin & Antimicrobial & Hydrolysis with pepsin & {$[36]$} \\
\hline
\end{tabular}


Recent studies have suggested that milk BPs may also contribute to reducing the risk of obesity and development of metabolic disorders. The size of these peptides may vary from two to more than 20 amino acids residues, and each defined peptide bioactivity is strictly linked to its structural features. In Table 1, some examples of the main BPs derived from casein and whey milk proteins are reported.

Some milk BPs show multifunctional properties [37]; for example, some regions in the primary structure of caseins contain overlapping peptide sequences that exert different biological effects (Table 1). These regions have been considered as 'strategic zones' which are partially protected from the proteolytic breakdown [38,39]; e.g., peptides from the sequence 60-70 ( $\beta$-casomorphin-11) and 60-66 ( $\beta$-casomorphin-7) of $\beta$-casein show immunostimulatory, opioid, and ACE-inhibitory activities. These sequences are protected from proteolysis because of their high hydrophobicity, which is due to the presence of proline and other hydrophilic amino acids. Neutral and basic amino acids are, instead, rapidly hydrolyzed. Moreover, it is interesting to highlight that some bioactive sequences include proline in their domain.

\section{Bioavailability}

The amount of peptides released upon digestion, as well as the beneficial effects of human health, are hardly predictable. It was estimated that the theoretical yield of opioid peptides encrypted in milk proteins ranged between $2 \%$ ( $\beta$-Casomorphin-5 from $\beta$-Casein, f60-64) and $6 \%$ ( $\alpha$-Lactorphin from $\alpha$-Lactalbumin, f50-53) starting from the precursor peptide [40]. BPs bioavailability is the ability of peptides to exert physiological effects in vivo after oral ingestion. Thus, it is of crucial importance that milk-derived BPs remain active during the gastrointestinal digestion and absorption and reach the target site intact. This means that milk-derived BPs have to be resistant to hydrolysis in the gastrointestinal tract in order to reach the peripheral organs [41]. The bioavailability of peptides depends on a variety of structural and chemical properties, i.e., resistance to proteases, charge, molecular weight, hydrogen bonding potential, hydrophobicity, and the presence of specific residues [42-44]. Indeed, proline- and hydroxyproline-containing peptides are relatively resistant to degradation by digestive enzymes [45-47]. The composition of the intestinal content, including food, significantly varies. The time that a peptide is present in the GI tract, as well as its absorption, are significantly affected by gastric emptying and intestinal transit. In addition, the peptide transport could be inhibited or favored (related to $\mathrm{pKa}$ of the peptide) by the physiological $\mathrm{pH}$.

For example, some milk-derived peptides have an in vitro inhibitory ACE activity compared to the relative synthetic ACE inhibitor, but exhibit high in vivo activity. This behavior was attributed to a greater affinity of BPs for tissues and their slower elimination [48], but other modes of action were hypothesized [16]. In contrast, some ACE-inhibitory peptides exhibit high activity in vitro but have no effects in vivo. For example, the peptide FFWAP derived from $\alpha$ s1-CN [49-51] is a potent ACE inhibitor in vitro but has no hypotensive effect in vivo [15]. Generally, the difficulty of establishing a direct relationship between in vitro and in vivo activity may depend on different reasons but it is clear that bioavailability after oral administration plays a key role. Despite numerous "in vitro" studies, further research is needed to clarify the relationship between the activity of BPs and their bioavailability. In this regard, the recent review by Nongonierma and FitzGerald, [52] summarizes the scientific evidence for the role of milk protein-derived BPs in humans and pointed out how double-blind randomized clinical trials based on the use of universal guidelines for the evaluation of BPs in humans are needed.

\section{Nutraceutical Aspects}

Numerous bioactive peptide fragments can be obtained through the hydrolysis of whole milk or via the precursor protein by digestive enzymes. This strongly leads us to hypothesize the production of such peptides in the GIT after the consumption of milk.

For these reasons, the potential that different BPs have to improve human health by reducing the risk of chronic diseases or by activating the immune response is gaining more and more 
interest within the scientific and commercial fields. In fact, since milk proteins are a rich source of natural active compounds, they could be used as ingredients for different applications and represent nutraceutical substances with potential health benefits that make them suitable for food and pharmaceutical applications [53].

\subsection{Methodology toward Innovative Aspects}

Processing techniques in laboratory and on industrial scale are now being developed for the extraction, fractionation and isolation of main proteins from milk [54-57], with particular attention to modern non-thermal, clean and green methodologies [58]. It is worth stressing, as already demonstrated by several studies, that each time a nutraceutical with potential health benefits is needed for a functional food, a specific enzymatic hydrolysis of milk proteins should be planned $[59,60]$. It is important to mention the review by Hafeez et al. [61] on different strategies for increasing the production of BPs from milk in order to obtain functionalized fermented products; the authors reported three types of methodology approaches: (1) proteolytic system of lactic acid bacteria (LAB) or food grade enzymes or a combined dual approach, (2) supplementation of the fermented milk products with the BPs obtained outside of the product, and (3) microorganisms using recombinant DNA technology [61]. Linares et al. [62] reviewed and discussed the use of health-supporting bacteria as starters or adjunct cultures for the development of dairy foods with targeted functional properties, including BPs.

\subsection{Applications}

The recent review by Mohanty et al. [63] gives a preliminary classification of bioactive milk-derived peptides and their impact on human health. It describes their physiological functions, general characteristics, and potentialities for improving health, as well as their nutraceutical and/or pharmaceutical applications. Besides their biochemical and physiological efficacy and versatility, milk-derived BPs are considered as ingredients of functional foods, as pointed out in a review by Park and Nam [64]. Milk BPs in dairy and non-dairy food formulations have been exploited, as shown by several authors [65-67]. The fractionation of bioactive milk ingredients represents a new, emerging sector of the market, which offers new and innovative products $[53,59,67]$. FitzGerald, et al. [68] exploited the hypotensive peptides from milk proteins and reported some examples of hypotensive dairy protein-derived products on the market such as a sour milk named "Calpis" (Calpis Co., Tokyo, Japan) or a fermented milk called "Evolus ${ }^{\circledR}$ " (Valio Oy, Helsinki, Finland) containing IPP and VPP peptides (peptides with hypotensive effect) from $\beta$ - and $\kappa$-casein. CalpisTM and Evolus ${ }^{\circledR}$ have been tested extensively in rats and in a clinical trial [69].

In addition, Korhonen, and Pihlanto, [70] have reported other commercial dairy products and ingredients having potential health benefits due to the presence of BPs, such as "BioZate" (Davisco Food International, Eden Prairie, MN, USA). It is a hydrolyzed whey protein that claims to reducing blood pressure. Another example is represented by "Vivinal Alpha," an ingredient/hydrolysate (Borculo Domo Ingredients-BDI-, Zwolle, The Netherlands) that favors relaxation and sleep.

Today, the recovery of BPs from milk and dairy industry byproducts has recently caught the attention of researchers in industrial biorefineries [71-73]. In order to solve the problem of the high environmental impact of byproducts deriving from cheese production industries, several new techniques are now employed to convert milk and dairy waste and byproducts into value-added products.

It is worth mentioning Patel et al. [74], who underline the emerging trends in nutraceutical applications of whey protein and its derivatives. To cite an example, Athira et al. [75] produced and characterized a whey protein hydrolysate with an antioxidant activity from cheese whey using the response surface methodology. In recent research, Abd El-Salam and El-Shibiny [76] have summarized today's ongoing research into the preparation, properties, and uses of enzymatic milk protein hydrolysates. 


\section{Conclusions}

The exploitation of the chemistry, bioavailability, and biochemical properties of BPs in cow's milk represent the basis for the development of nutraceutical and functional foods, in particular in the perspective of innovative applications in the field of circular bioeconomy. Moreover, for the use of these BPs as nutraceuticals, it is important to encourage clinical trials to test their effectiveness on humans and support the research through projects funded by public and private institutions.

Acknowledgments: The author thanks Annalisa Lista for the linguistic revision and editing of this paper.

Conflicts of Interest: The authors declare no conflict of interest.

\section{References}

1. Park, Y.W. Overview of bioactive components in milk and dairy products. In Bioactive Components in Milk and Dairy Products; Park, Y.W., Ed.; Wiley-Blackwell Publishers: Oxford, UK, 2009; pp. 3-14.

2. Baum, F.; Fedorova, M.; Ebner, J.; Hoffmann, R.; Pischetsrieder, M. Analysis of the endogenous peptide profile of milk: Identification of 248 mainly casein-derived peptides. J. Proteome Res. 2013, 12, 5447-5462. [CrossRef] [PubMed]

3. Walstra, P.; Jenness, R. Dairy Chemistry and Physics; John Wiley: New York, NY, USA, 1984.

4. Teschemacher, H.; Csontos, K.; Westenthanner, A.; Brantl, V.; Kromer, W. Endogenous opioids: Cold-induced release from pituitary tissue in vitro; extraction from pituitary and milk. In Endorphins in Mental Health Research; Usdin, E., Bunney, W.E., Kline, N.S., Eds.; Palgrave Macmillan: Basingstoke, UK, 1979; pp. $203-208$.

5. Phelan, M.; Aherne, A.; FitzGerald, R.J.; O’Brien, N.M. Casein-derived peptides: Biological effects, industrial uses, safety aspects and regulatory status. Int. Dairy J. 2009, 19, 643-654. [CrossRef]

6. Kamiński, S.; Cieslińska, A.; Kostyra, E. Polymorphism of bovine beta-casein and its potential effect on human health. J. Appl. Genet. 2007, 48, 189-198. [CrossRef] [PubMed]

7. European Food Safety Authority (EFSA). Review of the potential health impact of $\beta$-casomorphins and related peptides. Eur. Food Saf. Auth. 2009, 7. [CrossRef]

8. Lopez-Fandino, R.; Otte, J.; van Camp, J. Physiological, chemical and technological aspects of milk-protein-derived peptides with antihypertensive and ACE inhibitory activity. Int. Dairy J. 2006, 16, 1277-1293. [CrossRef]

9. Kamau, S.M.; Lu, R.-R.; Chen, W.; Liu, X.-M.; Tian, F.-W.; Shen, Y.; Gao, T. Functional significance of bioactive peptides derived from milk proteins. Food Rev. Int. 2010, 26, 386-401. [CrossRef]

10. Nagpal, R.; Behare, P.; Rana, R.; Kumar, A.; Kumar, M.; Arora, S.; Morotta, F.; Jain, S.; Yadav, H. Bioactive peptides derived from milk proteins and their health beneficial potentials: An update. Food Funct. 2011, 2, 18-27. [CrossRef] [PubMed]

11. Kitts, D.D.; Weiler, K. Bioactive proteins and peptides from food sources. Applications of bioprocesses used in isolation and recovery. Curr. Pharm. Des. 2003, 9, 1309-1323. [CrossRef] [PubMed]

12. Nielsen, S.D.; Beverly, R.L.; Qu, Y.; Dallas, D.C. Milk bioactive peptide database: A comprehensive database of milk protein-derived bioactive peptides and novel visualization. Food Chem. 2017. [CrossRef] [PubMed]

13. Meisel, H. Chemical characterization and opioid activity of an exorphin isolated from in vivo digests of casein. FEBS Lett. 1986, 196, 223-227. [CrossRef]

14. Cieślińska, A.; Kostyra, E.; Kostyra, H.; Oleński, K.; Fiedorowicz, E.; Kamiński, S. Milk from cows of different $\beta$-casein genotypes as a source of $\beta$-casomorphin-7. Int. J. Food Sci. Nutr. 2012, 63, 426-430. [CrossRef] [PubMed]

15. Maruyama, S.; Nakagomi, K.; Tomizuka, N.; Suzuki, H. Angiotensin I-converting enzyme inhibitor derived from an enzymatic hydrolysate of casein. II. Isolation and bradykinin-potentiating activity on the uterus and the ileum of rats. Agric. Biol. Chem. 1985, 49, 1405-1409.

16. Maruyama, S.; Suzuki, H. A peptide inhibitor of angiotensin I-converting enzyme in the tryptic hydrolysate of casein. Agric. Biol. Chem. 1982, 46, 1393-1394.

17. Maeno, M.; Yamamoto, N.; Takano, T. Identification of an antihypertensive peptide from casein hydrolysate produced by a proteinase from Lactobacillus helveticus CP790. J. Dairy Sci. 1996, 79, 1316-1321. [CrossRef] 
18. Migliore-Samour, D.; Floch, F.; Jollès, P. Biologically active casein peptides implicated in immunomodulation. J. Dairy Res. 1989, 56, 357-362. [CrossRef] [PubMed]

19. Kitazawa, H.; Yonezawa, K.; Tohno, M.; Shimosato, T.; Kawai, Y.; Saito, T.; Wang, J.M. Enzymatic digestion of the milk protein beta-casein releases potent chemotactic peptide(s) for monocytes and macrophages. Int. Immunopharmacol. 2007, 7, 1150-1159. [CrossRef] [PubMed]

20. Hayes, M.; Stanton, C.; Slattery, H.; O’Sullivan, O.; Hill, C.; Fitzgerald, G.F.; Ross, R.P. Casein fermentate of Lactobacillus animalis DPC6134, contains a range of novel propeptide angiotensin-converting enzyme inhibitors. Appl. Environ. Microbiol. 2007, 73, 4658-4667. [CrossRef] [PubMed]

21. Sato, R.; Shindo, M.; Gunshin, H.; Noguchi, T.; Naito, H. Characterization of phosphopeptide derived from bovine beta-casein: An inhibitor to intra-intestinal precipitation of calcium phosphate. Biochim. Biophys. Acta 1991, 1077, 413-415. [CrossRef]

22. Loukas, S.; Varoucha, D.; Zioudrou, C.; Streaty, R.A.; Klee, W.A. Opioid activities and structures of .alpha.-casein-derived exorphins. Biochemistry 1983, 22, 4567-4573. [CrossRef] [PubMed]

23. Karaki, H.; Doi, K.; Sugano, S.; Uchiwa, H.; Sugai, R.; Murakami, U.; Takemoto, S. Antihypertensive effect of tryptic hydrolysate of milk casein in spontaneously hypertensive rats. Comp. Biochem. Physiol. C 1990, 96, 367-371. [PubMed]

24. Minervini, F.; Algaron, F.; Rizzello, C.G.; Fox, P.F.; Monnet, V.; Gobbetti, M. Angiotensin I-converting-enzyme-inhibitory and antibacterial peptides from Lactobacillus helveticus PR4 proteinase-hydrolyzed caseins of milk from six species. Appl. Environ. Microbiol. 2003, 69, 5297-5305. [CrossRef] [PubMed]

25. Srinivas, S.; Prakash, V. Bioactive peptides from bovine milk alpha-casein: Isolation, characterization and multifunctional properties. Int. J. Pept. Res. Ther. 2010, 16, 7-15. [CrossRef]

26. Yoshikawa, M.; Tani, F.; Ashikaga, T.; Yoshimura, T.; Chiba, H. Purification and Characterization of an Opioid Antagonist from a Peptic Digest of Bovine k-Casein. Agric. Biol. Chem. 1986, 50, 2951-2954. [CrossRef]

27. Chiba, H.; Tani, F.; Yoshikawa, M. Opioid antagonist peptides derived from kappa-casein. J. Dairy Res 1989, 56, 363-366. [CrossRef] [PubMed]

28. Jollès, P.; Lévy-Toledano, S.; Fiat, A.M.; Soria, C.; Gillessen, D.; Thomaidis, A.; Dunn, F.W.; Caen, J.P. Analogy between fibrinogen and casein. Effect of an undecapeptide isolated from kappa-casein on platelet function. Eur. J. Biochem. 1986, 158, 379-382. [CrossRef] [PubMed]

29. Patten, G.S.; Head, R.J.; Abeywardena, M.Y. Effects of casoxin 4 on morphine inhibition of small animal intestinal contractility and gut transit in the mouse. Clin. Exp. Gastroenterol. 2011, 4, 23-31. [CrossRef] [PubMed]

30. Nurminen, M.L.; Sipola, M.; Kaarto, H.; Pihlanto-Leppälä, A.; Piilola, K.; Korpela, R.; Tossavainen, O.; Korhonen, H.; Vapaatalo, H. Alpha-lactorphin lowers blood pressure measured by radiotelemetry in normotensive and spontaneously hypertensive rats. Life Sci. 2000, 66, 1535-1543. [CrossRef]

31. Mullally, M.M.; Meisel, H.; FitzGerald, R.J. Synthetic peptides corresponding to alpha-lactalbumin and beta-lactoglobulin sequences with angiotensin-I-converting enzyme inhibitory activity. Biol. Chem. Hoppe Seyler 1996, 377, 259-260. [PubMed]

32. FitzGerald, R.J.; Meisel, H. Lactokinins: Whey protein-derived ACE inhibitory peptides. Nahrung 1999, 43, 165-167. [CrossRef]

33. Mullally, M.M.; Meisel, H.; FitzGerald, R.J. Identification of a novel angiotensin-I-converting enzyme inhibitory peptide corresponding to a tryptic fragment of bovine beta-lactoglobulin. FEBS Lett. 1997, 402, 99-101. [CrossRef]

34. Yamauchi, R.; Ohinata, K.; Yoshikawa, M. Beta-lactotensin and neurotensin rapidly reduce serum cholesterol via NT2 receptor. Peptides 2003, 24, 1955-1961. [CrossRef] [PubMed]

35. Tani, F.; Shiota, A.; Chiba, H.; Yoshikawa, M. Serophin, an opioid peptide derived from serum albumin. In $\beta$-Casomorphins and Related Peptides: Recent Developments; Brantl, V., Teschemacher, H., Eds.; Wiley: Weinheim, Germany, 1994; pp. 49-53.

36. Meisel, H.; Bockelmann, W. Bioactive peptides encrypted in milk proteins: Proteolytic activation and thropho-functional properties. Antonie Van Leeuwenhoek 1999, 76, 207-215. [CrossRef] [PubMed]

37. Meisel, H. Multifunctional peptides encrypted in milk proteins. Biofactors 2004, 21, 55-61. [CrossRef] [PubMed] 
38. Fiat, A.M.; Jolles, P. Caseins of various origins and biologically active casein peptides and oligosaccharides: Structural and physiological aspects. Mol. Cell. Biochem. 1989, 87, 5-30. [CrossRef] [PubMed]

39. Meisel, H. Overview on milk protein-derived peptides. Int. Dairy J. 1998, 8, 363-373. [CrossRef]

40. Meisel, H.; FitzGerald, R.J. Opioid peptides encrypted in milk proteins. Br. J. Nutr. 2000, 84, S27-S31. [CrossRef] [PubMed]

41. Vermeirssen, V.; van Camp, J.; Verstraete, W. Bioavailability of angiotensin I-converting enzyme inhibitory peptides. Br. J. Nutr. 2004, 92, 357-366. [CrossRef] [PubMed]

42. Ganapathy, V.; Brandsch, M.; Leibach, F.H. Intestinal transport of amino acids and peptides. In Physiology of the Gastrointestinal Tract; Johnson, L.R., Ed.; Raven Press Ltd.: New York, NY, USA, 1994; pp. 1773-1794.

43. Pauletti, G.M.; Gangwar, S.; Knipp, G.T.; Nerurkar, M.M.; Okumu, F.W.; Tamura, K.; Siahaan, T.J.; Borchardt, R.T. Structural requirements for intestinal absorption of peptide drugs. J. Control. Release 1996, 41, 3-17. [CrossRef]

44. Pauletti, G.M.; Okumu, F.W.; Borchardt, R.T. Effect of size and charge on the passive diffusion of peptides across Caco-2 cell monolayers via the paracellular pathway. Pharm. Res. 1997, 14, 164-168. [CrossRef] [PubMed]

45. Cardillo, G.; Gentilucci, L.; Tolomelli, A.; Calienni, M.; Qasem, A.R.; Spampinato, S. Stability against enzymatic hydrolysis of endomorphin-1 analogues containing beta-proline. Org. Biomol. Chem. 2003, 1, 1498-1502. [CrossRef] [PubMed]

46. Mizuno, S.; Nishimura, S.; Matsuura, K.; Gotou, T.; Yamamoto, N. Release of short and proline-rich antihypertensive peptides from casein hydrolysate with an Aspergillus oryzae protease. J. Dairy Sci. 2004, 87, 3183-3188. [CrossRef]

47. Savoie, L.; Agudelo, R.A.; Gauthier, S.F.; Marin, J.; Pouliot, Y. In vitro determination of the release kinetics of peptides and free amino acids during the digestion of food proteins. J. AOAC Int. 2005, 88, 935-948. [PubMed]

48. Fujita, H.; Yoshikawa, M. LKPNM: A prodrug-type ACE-inhibitory peptide derived from fish protein. Immunopharmacology 1999, 44, 123-127. [CrossRef]

49. Svedberg, J.; de Hass, J.; Leimenstoll, G.; Paul, F.; Teschemacher, H. Demonstration ofmbeta-casomorphin immunoreactive materials in in vitro digests of bovine milk and in small intestine contents after bovine milk ingestion in adult humans. Peptides 1985, 6, 825-830. [CrossRef]

50. Matar, C.; Amiot, J.; Savoie, L.; Goulet, J. The effect of milk fermentation by Lactobacillus helveticus on the release of peptides during in vitro digestion. J. Dairy Sci. 1996, 79, 971-979. [CrossRef]

51. Miquel, E.; Gomez, J.A.; Alegria, A.; Barbera, R.; Farre, R.; Recio, I. Identification of casein phosphopeptides released after simulated digestion of milk-based infant formulas. J. Agric. Food Chem. 2005, 53, 3426-3433. [CrossRef] [PubMed]

52. Nongonierma, A.B.; FitzGerald, R.J. The scientific evidence for the role of milk protein-derived bioactive peptides in humans: A review. J. Funct. Foods 2015, 17, 640-656. [CrossRef]

53. Hartmann, R.; Meisel, H. Food-derivedpeptides with biological activity: From research to food applications. Curr. Opin. Biotechnol. 2007, 18, 1-7. [CrossRef] [PubMed]

54. Capriotti, A.L.; Cavaliere, C.; Piovesana, S.; Samperi, R.; Laganà, A. Recent Trends in the analysis of bioactive peptides in milk and dairy products. Anal. Bioanal. Chem. 2016, 408, 2677-2685. [CrossRef] [PubMed]

55. Muro Urista, C.; Álvarez Fernández, R.; Riera Rodriguez, F.; Arana Cuenca, A.; Téllez Jurado, A. Review: Production and functionality of active peptides from milk. Food Sci. Technol. Int. 2011, 17, 293-317. [CrossRef] [PubMed]

56. Dallas, D.C.; Lee, H.; Parc, A.L.; de Moura Bell, J.M.L.N.; Barile, D. Coupling Mass Spectrometry-Based "Omic" Sciences with Bioguided Processing to Unravel Milk's Hidden Bioactivities. Adv. Dairy Res. 2013, 1, 104. [CrossRef]

57. Sánchez-Rivera, L.; Martínez-Maqueda, D.; Cruz-Huerta, E.; Miralles, B.; Recio, I. Peptidomics for discovery, bioavailability and monitoring of dairy bioactive peptides. Food Res. Int. 2014, 63, 170-181. [CrossRef]

58. Kareb, O.; Gomaa, A.; Champagne, C.P.; Jean, J.; Aïder, M. Electro-activation of sweet defatted whey: Impact on the induced Maillard reaction products and bioactive peptides. Food Chem. 2017, 221, 590-598. [CrossRef] [PubMed]

59. Pihlanto-Leppälä, A. Bioactive peptides derived from bovine whey proteins: Opioid and ace-inhibitory peptides. Trends Food Sci. Technol. 2000, 11, 347-356. [CrossRef] 
60. Bitri, L. Optimization Study for the Production of an Opioid-like Preparation from Bovine Casein by Mild Acidic Hydrolysis. Int. Dairy J. 2004, 14, 535-539. [CrossRef]

61. Hafeez, Z.; Cakir-Kiefer, C.; Roux, E.; Perrin, C.; Miclo, L.; Dary-Mourot, A. Strategies of producing bioactive peptides from milk proteins to functionalize fermented milk products. Food Res. Int. 2014, 63, 71-80. [CrossRef]

62. Linares, D.M.; Gómez, C.; Renes, E.; Fresno, J.M.; Tornadijo, M.E.; Ross, R.P.; Stanton, C. Lactic Acid Bacteria and Bifidobacteria with Potential to Design Natural Biofunctional Health-Promoting Dairy Foods. Front. Microbiol. 2017, 8. [CrossRef] [PubMed]

63. Mohanty, D.P.; Mohapatra, S.; Misra, S.; Sahu, P.S. Milk derived bioactive peptides and their impact on human health-A review. Saudi J. Biol. Sci. 2016, 23, 577-583. [CrossRef] [PubMed]

64. Park, Y.W.; Nam, M.S. Bioactive Peptides in Milk and Dairy Products: A Review. Korean J. Food Sci. Anim. Resour. 2015, 35, 831-840. [CrossRef] [PubMed]

65. Krissansen, G.W. Emerging health properties of whey proteins and their clinical implications. J. Am. Coll. Nutr. 2007, 26, 713S-723S. [CrossRef] [PubMed]

66. Korhonen, H.; Pihlanto, A. Food-derived bioactive peptides-Opportunities for designing future foods. Curr. Pharm. Des. 2003, 9, 1297-1308. [CrossRef] [PubMed]

67. Korhonen, H.; Marnila, P. Bovine milk antibodies for protection against microbial human diseases. In Nutraceutical Proteins and Peptides in Health and Disease; Mine, Y., Shahidi, S., Eds.; Taylor \& Francis Group: Boca Raton, FL, USA, 2005; pp. 137-159.

68. FitzGerald, R.J.; Murray, B.A.; Walsh, D.J. Hypotensive peptides from milk proteins. J. Nutr. 2004, 134, 980-988.

69. Dziuba, B.; Dziuba, M. Milk proteins-derived bioactive peptides in dairy products: Molecular, biological and methodological aspects. Acta Sci. Pol. Technol. Aliment. 2014, 13, 5-25. [CrossRef] [PubMed]

70. Korhonen, H.; Pihlanto, A. Bioactive peptides: Production and functionality. Int. Dairy J. 2006, 16, 945-960. [CrossRef]

71. Brandelli, A.; Daroit, D.J.; Folmer Corrêa, A.P. Whey as a source of peptides with remarkable biological activities. Food Res. Int. 2015, 73, 149-161. [CrossRef]

72. Yadav, J.S.; Yan, S.; Pilli, S.; Kumar, L.; Tyagi, R.D.; Surampalli, R.Y. Cheese whey: A potential resource to transform into bioprotein, functional/nutritional proteins and bioactive peptides. Biotechnol. Adv. 2015, 33, 756-774. [CrossRef] [PubMed]

73. Sommella, E.; Pepe, G.; Ventre, G.; Pagano, F.; Conte, G.M.; Ostacolo, C.; Manfra, M.; Tenore, G.; Russo, M.; Novellino, E.; et al. Detailed peptide profiling of "Scotta": From a dairy waste to a source of potential health-promoting compounds. Dairy Sci. Technol. 2016, 96, 763-771. [CrossRef]

74. Patel, S. Emerging trends in nutraceutical applications of whey protein and its derivatives. J. Food Sci. Technol. 2015, 52, 6847-6858. [CrossRef] [PubMed]

75. Athira, S.; Mann, B.; Saini, P.; Sharma, R.; Kumar, R.; Singh, A.K. Production and characterisation of whey protein hydrolysate having antioxidant activity from cheese whey. J. Sci. Food Agric. 2015, 95, 2908-2915. [CrossRef] [PubMed]

76. Abd El-Salam, M.H.; El-Shibiny, S. Preparation, properties, and uses of enzymatic milk protein hydrolysates. Crit. Rev. Food Sci. Nutr. 2017, 57, 1119-1132. [CrossRef] [PubMed]

(C) 2017 by the author. Licensee MDPI, Basel, Switzerland. This article is an open access article distributed under the terms and conditions of the Creative Commons Attribution (CC BY) license (http:// creativecommons.org/licenses/by/4.0/). 